\title{
"O GRANDE DESASTRE AÉREO DE ONTEM": ONIRISMO, MONTAGEM POÉTICA E RESSONÂNCIAS DE MARC CHAGALL EM JORGE DE LIMA
}

\author{
"O GRANDE DESASTRE AÉREO DE ONTEM": \\ ONIRISM, POETIC MONTAGE AND RESONANCES OF MARC \\ CHAGALL IN JORGE DE LIMA
}

Luciano Marcos Dias Cavalcanti ${ }^{1}$

RESUMO: Nesse texto, pretendemos fazer a análise do poema “O grande desastre aéreo de ontem", de modo a perceber as ressonâncias da obra pictural de Marc Chagall na poesia de Jorge de Lima. Para isto estudaremos a relaçăo que os dois artistas empreendem em suas obras com o onirismo e a montagem poética.

PALAVRAS-CHAVE: Jorge de Lima; Marc Chagall; montagem; onirismo

ABSTRACT: In this text, we plan to make the analysis of the poem "O grande desastre aéreo de ontem", in order to perceive the resonances of Marc Chagall's pictorial work in the poetry of Jorge de Lima. For that, we'll study the relation that both artists undertake in their works with the onirism and the poetic assembly.

KEYWORDS: Jorge de Lima; Marc Chagall; Assembly; onirism

\section{Introdução}

Em um texto importante sobre a poesia de Jorge de Lima, "Nota preliminar" A Túnica Inconsútil, ${ }^{2}$ Mário de Andrade reflete sobre o caráter hermético do poeta alagoano. De acordo como o crítico,

a significaçăo de Jorge de Lima, a personalidade deste grande poeta brasileiro talvez nunca tenha já estado tâo misteriosa como depois da publicaçăo do seu último livro de poesia: A Túnica Inconsútil. Eis um artista que năo poderá ser perfeitamente compreendido, ou pelo menos explicado, sem uma exegese bastante pormenorizada. Jorge de Lima é um mundo de contradiçōes por explicar e de dificuldades a resolver (ANDRADE, 1958, p. 417).

1 Universidade Vale do Rio Verde, Três Coraçôes, Doutor em Teoria e História Literária IEL-UNICAMP. Professor do Mestrado em Letras: linguagem, cultura e discurso. E-mail: prof.luciano.cavalcanti@ unincor.edu.br

2 Texto publicado originalmente em O Estado de Sâo Paulo, Sáo Paulo, 8 de janeiro de 1939, sob o título “A Túnica inconsútil". 
Mário continua precavendo os leitores de A Túnica Inconsútil sobre a dificuldade para a explicaçăo da poesia de Jorge de Lima. A isso, acrescenta-se o engano de considerar que a composiçấo poética limiana é um deixar correr à pena numa livre fruiçăo poética. O que mais caracteriza, a seu ver, os poemas de A Túnica Inconsútil é a "prudência", ou seja, a preocupaçăo com a composiçăo poética, por meio do zelo - para o crítico, até mesmo exagerado, no entanto positivo - construtivo de seus poemas.

Năo é com qualquer verbalismo, năo é com a substituiçăo do poeta por qualquer palavra, ou três e quatro palavras classificadoras, que ele se explica. Todo ele obriga a distinçōes e explanaçōes, principalmente porque năo haverá talvez na poesia brasileira ninguém que mais tenha sabido converter defeitos gerais em qualidades particulares ou descoberto o aspecto favorável e útil dos perigos. Assim é, por exemplo, que num poeta cujos versos constantemente nos dáo a impressăo de rápida espontaneidade, que tem usado e talvez mesmo abusado de toda a temática moderna de poesia, há, de início e permanentemente, aquilo que mais faltou à genialidade de Castro Alves: uma grande prudência (ANDRADE, 1958, p. 418).

Segundo Mário de Andrade, este zelo encontrado em Jorge de Lima foi deixado de lado pelos poetas modernistas; conscienciosos de se livrarem das amarras parnasianas, abandonaram a prudência, combatendo e ignorando-a. Dessa forma, o poeta "nâo deixa jamais que uma imprudência de concepçăo e de expressăo possa servir de descaminho aos outros. Os seus cacoetes se os tem, săo de tal forma evasivos que ninguém os pega no voo." (ANDRADE, 1958, p. 419). É pelo diálogo franco com os cânones, sem ser um repetidor dos "princípios" parnasianos, que Jorge de Lima retira sua força poética: “E deste academismo, desta obediência altiva ao cânone, que a obra de Jorge de Lima beneficia. No momento, ela será talvez a poesia mais clássica do Brasil contemporâneo." (ANDRADE, 1958, p. 419). A esta postura "clássica" limiana acrescenta-se outra virtude (ou "defeito", como quer Mário), o intenso diálogo intertextual (caracterizado por Mário como uma "falta de invençâo poética") com os grandes clássicos ocidentais, exemplarmente verificável em $A$ Túnica Inconsútil.

Se Jorge de Lima tivesse vivido alguns séculos atrás teria sido por certo um desses grandes plagiários, à feiçăo de Shakespeare ou de Camôes. Năo creio que com a mesma força de genialidade, estas aproximaçôes săo sempre muito perigosas, mas da mesma qualidade que eles. Quero dizer; Jorge de Lima plagiaria, da mesma forma sempre criadora, com que Camóes plagiou o Super Flumina Babylonis no "Sobolos rios que váo". Dos poemas importantes de Jorge de Lima (e A Túnica Inconsútil pôde perfeitamente ser considerada um poema só, como quer o poeta), dos poemas importantes de Jorge de Lima náo haverá talvez um único, de que năo se possa descobrir a fonte de inspiraçăo noutro poema moderno brasileiro. Inda mais: um livro como A Túnica Inconsútil tem um sabor antológico, de tal forma o poeta compila nas suas páginas toda a temática posta em fogo pela poesia contemporânea... franco-brasileira. Aparece a estrela, aparece o anjo, comparecem o marinheiro, o violonista, a dançarina, o mágico o circo e o music-hall inteiros (ANDRADE, 1958, pp. 419-20).

Acresce-se ainda, na poesia de Jorge de Lima, o seu caráter imaginativo-religioso, que na perspectiva de Mário de Andrade se confunde com a sensibilidade no fazer poético: "Todo este seu livro novo, um dos melhores que já produziu, está cheio da mais 
rica e mesmo surpreendente imaginaçăo. [...] perfeitamente explicável pelo sentido religioso deste poema." (ANDRADE, 1958, p. 420). Mas a "grande liçấo" da obra de Jorge de Lima pode ser notada precisamente na

qualidade lírica da sua imaginaçăo. Esta será por certo a grande liçáo da obra de Jorge de Lima dentro de nossa poesia contemporânea. Dominado por uma prudência, visivelmente exercitada na observaçáo e no raciocínio, o poeta possui uma bússola fecunda e prefixada que náo lhe permite mais errar. E entăo dá largas à criaçăo, despreocupado com quaisquer disciplinas intercorrentes. É a própria criaçáo que se dirige a si mesma, por associaçóes, por antíteses, por enumeraçôes que nada têm de lógicas como as de Whitman, numa grande e admirável liberdade (ANDRADE, 1958, pp. 420-21).

É por tudo isso que Mário conclui seu texto, afirmando que "năo disse senâo a menor parte de tudo quanto faz de Jorge de Lima o 'caso' mais apaixonante da poesia brasileira contemporânea do Brasil." (ANDRADE, 1958, p. 421).

O significado do título do livro de Jorge de Lima é proveniente de uma passagem bíblica, descrita no Evangelho de Sâo Joâo (BÍBLIA, Săo Joăo, 19: 23-24), episodio pós-crucificaçấo de Cristo, momento em que os soldados o levam para sua sepultura e dividem suas vestes em quatro partes, uma para cada soldado. No entanto, a túnica feita sem nenhum tipo de costura foi preservada em sua totalidade. Nas palavras de Roger Bastide:

A túnica é o largo e amplo vestuário do mundo, mas sem costura. Quer dizer que o poeta poderá continuar muito bem no mundo da multiplicidade, mas abolindo as fronteiras que separam os objetos para reencontrar assim, por meio de um subterfúgio indireto, a unidade essencial das coisas (BASTIDE, 1997, pp. 125-126).

Simbolicamente, isso também pode significar que o manto de Cristo representa uma grande unidade que protege toda a humanidade. Em seu sentido poético, sugere que seu livro, ou até mesmo toda a sua lírica, é um grande corpo poético, que, como este manto, pretende envolver cristianamente a humanidade.

Jorge de Lima é um poeta reconhecidamente múltiplo, conforme atesta sua produçăo artística em geral. Percorreu vários caminhos em sua atividade literária: poeta, romancista e crítico. A estas, soma-se sua atividade de pintor, escultor e de operador de fotomontagens. Um dos mecanismos que Jorge de Lima utiliza em sua expressăo poética é o da fragmentaçăo e recomposiçăo do real em uma nova imagem, recurso iniciado em Tempo e Eternidade, adensado em A Túnica Inconsútil e mais bem caracterizado em Anunciaçāo e Encontro de Mira-Celi e no Livro de Sonetos, aspectos que o levam a estar cada vez mais próximo do hermetismo característico de Invençâo de Orfeu.

A fragmentaçấo e a recomposiçâo do real em uma nova imagem provêm, seguramente, da experiência com o Surrealismo, no qual a associaçáo de elementos opostos ou contraditórios era usada para criar uma imagem nova, muitas vezes insólita, conforme atesta a poesia de Jorge de Lima e suas famosas colagens, denominadas A pintura em pânico (1943). Naquele momento, o poeta é anunciado por Murilo Mendes como um artista em dia com os movimentos internacionais, remetendo os leitores a Rimbaud, Max Ernest e Salvador Dalí. As leituras de Freud e Jung, feitas entre os anos de 1920 e 1927 pelo entâo médico, podem também ser apontadas como 
responsáveis por esse mundo caracteristicamente onírico. A esse universo, Jorge de Lima transfere toda a bagagem visual dos sonhos, das visóes e das fantasias acumuladas desde a infância. Esta perspectiva composicional se revela amplamente em "O grande desastre aéreo de ontem", de A Túnica Inconsútil, ${ }^{3}$ poema em prosa, dedicado a Portinari, em que suas imagens nos remetem às figuras esvoaçantes de Marc Chagall.

É importante ressaltar que, entre as múltiplas atividades artísticas de Jorge de Lima, sua relaçấo com a pintura é relevante e complementar de sua poesia. O próprio poeta, em seu Auto-retrato Intelectual, assevera sobre a relaçâo entre a poesia e a pintura em sua obra: "Já disse e repito: minha pintura, deficiente, imperfeita, autodidata é tăo somente um complemento de minha poesia." (LIMA, 1958, p.79). Jorge de Lima ilustrou vários de seus livros de poemas: 0 mundo menino impossível, Essa negra Fulô, Vinte sonetos, As ilhas, o que demonstra sua preocupaçăo com a complementaçăo ou ampliaçăo de sua obra poética por meio da junçăo da imagem figurativa aos seus versos. Somam-se a isso as ilustraçóes de sua obra, feita por vários artistas plásticos: Manuel Bandeira ilustrou os Poemas escolhidos, Santa Rosa, o romance $O$ anjo, Di Cavalcanti fez estudos sobre o seu poema mais conhecido "Essa Negra Fulô", assim como Lasar Segall que também fez ilustraçōes dos Poemas Negros. Fayga Ostrower ilustrou Invençâo de Orfeu e Cândido Portinari4 (também poeta) o retratou em 1937, a quem, como dissemos, o poeta dedica "O grande desastre aéreo de ontem". Todos săo artistas que conviveram com o poeta e frequentaram seu famoso consultório médico da Cinelândia, espaço no qual Jorge de Lima se dividia entre o oficio da medicina (atendendo seus pacientes) e das artes (recebendo seus amigos artistas).

Após apresentarmos A túnica Inconsútil, livro em que Jorge de Lima publicou "O grande desastre aéreo de ontem" e sucintamente apontarmos algumas relaçôes entre o poeta e as artes plásticas, desenvolvermos os argumentos do artigo considerando alguns pontos, divididos em seçóes, com o intuito de estabelecer - de maneira didática - algumas relaçóes entre a poesia e a pintura, o onirismo e a arte, as peculiaridades da obra de Marc Chagal e uma possível ressonância da obra do pintor no poema de Jorge de Lima.

3 A Túnica Inconsútil, "momento alto da poesia mística brasileira" (BOSI, 1999, p.454), dá continuidade e aprofunda a poesia anterior de Jorge de Lima, que já desenvolvia em Tempo e Eternidade, de fundo místicoreligiosa, prática católico-social de seu tempo. No Brasil, esta tendência foi difundida principalmente por Alceu Amoroso Lima e Jackson de Figueiredo, fundador da revista A Ordem (1921) e do Centro Dom Vital (1922). Antonio Candido comenta a presença da tendência religiosa nas décadas de 20 e 30 no Brasil: “Além do engajamento espiritual e social dos intelectuais católicos, houve na literatura algo mais difuso e insinuante: a busca de uma tonalidade espiritualista de tensâo e mistério, que sugerisse, de um lado, o inefável, de outro, o fervor; e que aparece em autores tăo diversos quanto Otávio de Faria, Lúcio Cardoso, Cornélio Pena, na ficçāo; ou Augusto Frederico Schmidt, Jorge de Lima, Murilo Mendes, o primeiro Vinícius de Moraes, na poesia. (...) Naquela altura o catolicismo se tornou uma fé renovada, um estado de espírito e uma dimensầo estética. 'Deus está na moda', disse com razăo André Gide em relaçăo ao que ocorria na França e era verdade também no Brasil." (CANDIDO, 1987, p. 188).

4 De acordo com Ana Maria Paulino, Jorge de Lima, faz uma crítica ao amigo pintor no número 48 da Revista Acadêmica, ressaltando a "'solidez' dos quadros e a 'prudência de seu desenho clássico'. Vê em Portinari 'parentesco com o universal', com os pintores mundiais do momento, e destaca ainda, no artista, 'absoluto controle (mesmo quando lhe apraz deformar) da medida, do desenho, da composiçáo geometricamente bem distribuída"' (PAULINO, 1995, p. 61). 


\section{"0 grande desastre aéreo de ontem"}

Para Portinari

Vejo sangue no ar, vejo o piloto que levava uma flor para a noiva, abraçado com a hélice. E o violinista em que a morte acentuou a palidez, despenhar-se com sua cabeleira negra e seu estradivárius. Há máos e pernas de dançarinas arremessadas na explosâo. Corpos irreconhecíveis identificados pelo Grande Reconhecedor. Vejo sangue no ar, vejo chuva de sangue caindo nas nuvens batizadas pelo sangue dos poetas mártires. Vejo a nadadora belíssima, no seu último salto de banhista, mais rápida porque vem sem vida. Vejo três meninas caindo rápidas, enfunadas, como se dançassem ainda. E vejo a louca abraçada ao ramalhete de rosas que ela pensou ser o paraquedas, e a prima-dona com a longa cauda de lantejoulas riscando o céu como um cometa. E o sino que ia para uma capela do oeste, vir dobrando finados pelos pobres mortos. Presumo que a moça adormecida na cabine ainda vem dormindo, tăo tranquila e cega! Ó amigos, o paralítico vem com extrema rapidez, vem como uma estrela cadente, vem com as pernas do vento. Chove sangue sobre as nuvens de Deus. E há poetas míopes que pensam que é o arrebol. (LIMA, 1958, p. 446)

\section{MARC CHAGALL 5}

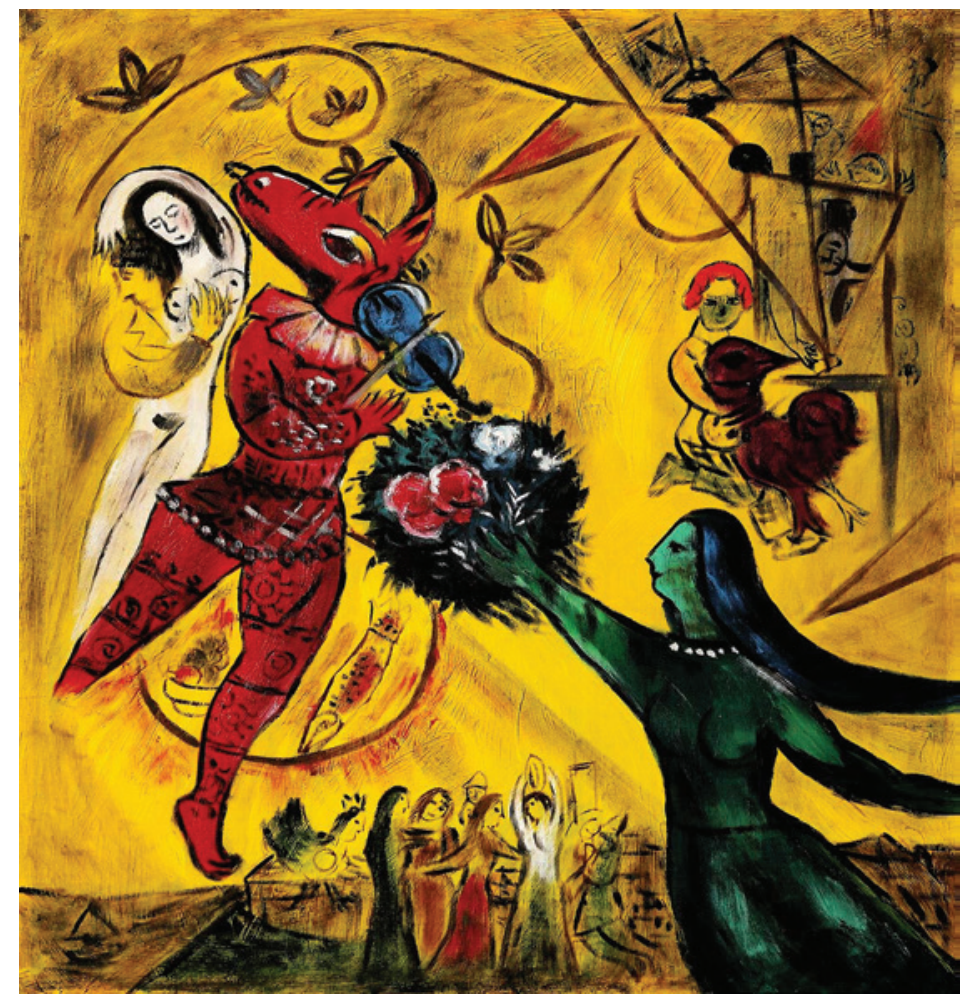

"A dança" - Marc Chagall

$5 \quad$ Todas as reproduçōes das obras de Marc Chagall foram retiradas do site: <https://www.wikiart.org/pt/ marc-chagall>. Acesso em 30-10-2017. 


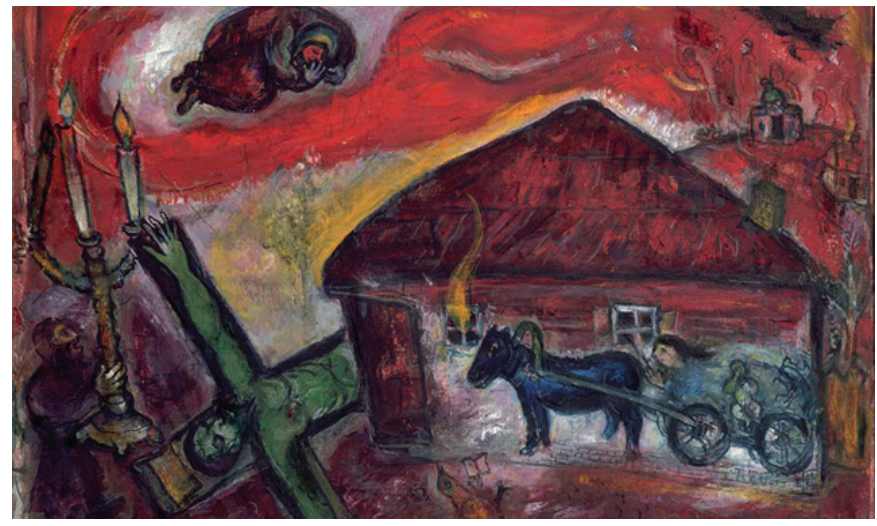

"Obsessão" - Marc Chagall

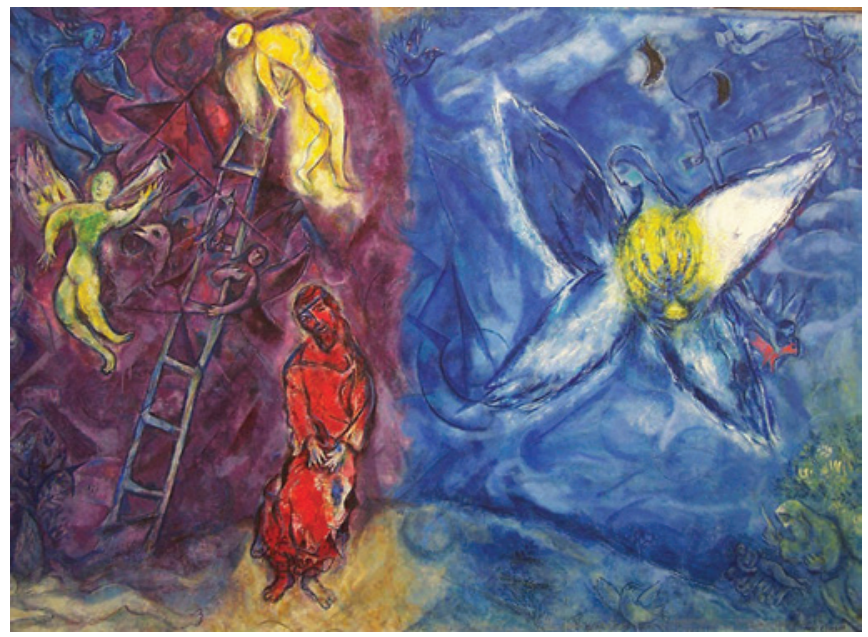

"O sonho de Jacob" - Marc Chagall

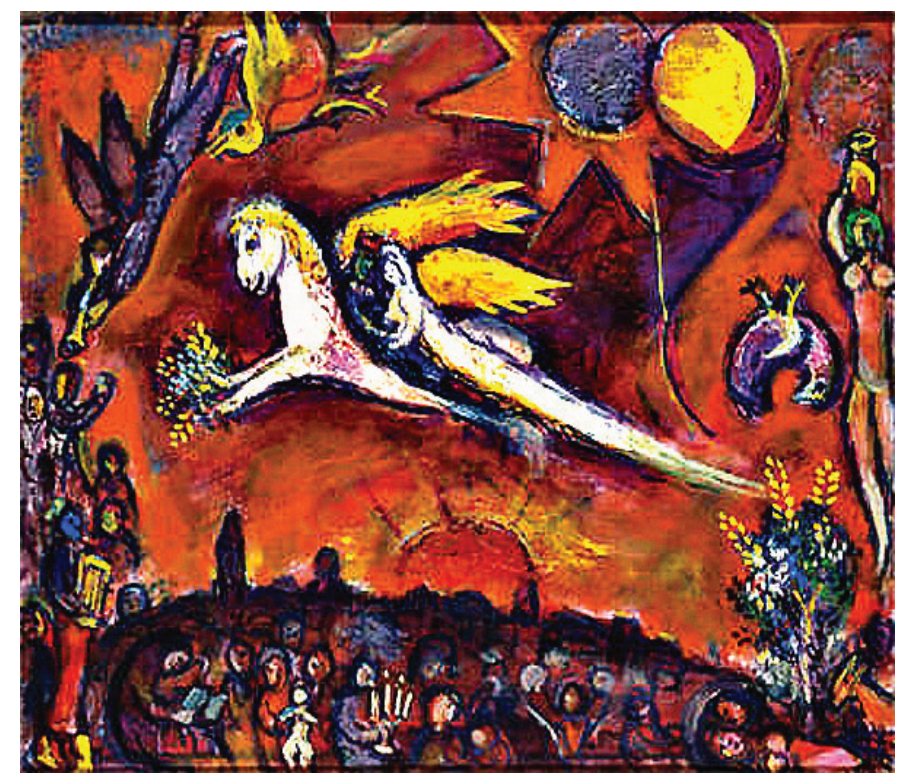

"Cantar dos Cantares" - Marc Chagall 


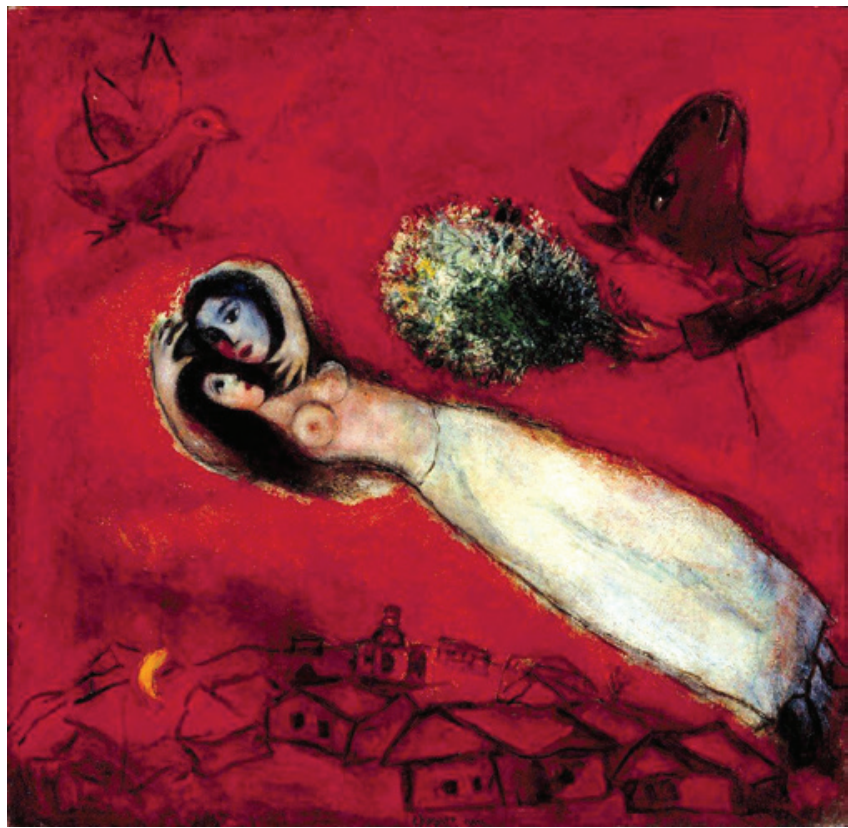

"Amantes no céu vermelho" - Marc Chagall

\title{
Ut pictura poesis
}

Ler um texto poético ou observar um quadro é, em princípio, percorrer com o olhar duas representaçôes artísticas distintas. No primeiro caso, o observador-leitor necessita decifrar o conjunto gráfico que forma o texto por meio de seu ritmo, de suas metáforas, de suas escolhas lexicais etc. No segundo, o observador, quando vislumbra um quadro, percorre com o olhar um mundo de formas, texturas, espaços, cores etc., e deve interpretá-lo. Nesse sentido, o sucesso da comparaçăo de dois sistemas semióticos distintos vai depender de como o analista articula cada sistema de forma conjunta sem deixar de considerar a particularidade de cada um.

De acordo com Aguinaldo Gonçalves, para analisarmos comparativamente um objeto artístico devemos inicialmente observar sua linguagem própria e, depois, ter consciência da mobilidade proveniente dos procedimentos distintos que se inter-relacionam. Para o crítico,

\begin{abstract}
estes procedimentos săo responsáveis pela construçâo da imagem que singulariza o objeto conhecido e podem se dar por relaçôes de contiguidade, por relaçóes de similaridade, ou ainda pela sobreposiçăo de ambas, e é a partir desses procedimentos que podemos falar de relaçôes analógicas, homológicas e associativas. [...] estas formas de relaçâo [sâo] imprescindíveis para qualquer funcionamento mental e completamente indispensáveis para o estudo das relaçôes entre sistemas artísticos [distintos] [...] (GONÇALVES, 1997, p. 57).
\end{abstract}

O crítico ainda acrescenta que para analisarmos comparativamente literatura e outras artes, devemos trocar a simples perspectiva analógica (semelhança de temas) para realizarmos uma abordagem homológica (semelhança estrutural). A perspectiva analógica deve vir na abordagem crítica como "ponto de partida" para uma análise apurada ulterior, mais complexa e sutil, é como uma "porta de entrada" para 
que, posteriormente, se possa detectar "modelos mais rigorosos que, na verdade, vâo buscar correspondências, equivalências homológicas entre estruturas distintas." (JAKOBSON apud GONÇALVES, 1997, p. 58). É essa perspectiva que possibilita ao analista, de maneira mais efetiva, fazer analogias mais fecundas entre as artes.

O movimento abstrato entre a expressăo artística e a plástica é captado pela

manifestaçáo do poético, engendrado por meios distintos de expressáo, mas cujo caráter singular advinha, em todos eles, do modo de construçáo que acabava sempre no mesmo resultado: a composiçáo da metáfora. Entretanto, cada um deles privilegiava, em si, graças ao próprio meio de que ambos se valiam, instâncias sensoriais e abstratas distintas: na poesia, pelo ritmo engendrado, o diagrama emergente e primordial; na pintura, pelas relaçōes instauradas, a emergência do poético, por formas transfiguradas no espaço e recompostas na simultaneidade do tempo (GONÇALVES, 1997, p. 59; grifos nossos.).

Assim como lembra Horácio na fórmula que imprime o paralelismo entre pintura e poesia (Ut pictura poesis - A poesia é como a pintura) é possível perceber uma relaçăo estreita entre o poema "O grande desastre aéreo de ontem", de Jorge de Lima, e a poética pictural de Marc Chaggall, que pode ser percebida no uso do onirismo e da montagem poética. Dessa maneira, o leitor do poema de Jorge de Lima é levado a se situar como espectador, como quem observa uma exposiçăo da obra pictural de Marc Chagall. Ou mais do que isso, o leitor do poema reconhece a poética de Chagall nos versos de Jorge de Lima.

\section{o onirismo e a arte}

a repulsa ao realismo positivista, que para a imaginaçáo criadora significa um empecilho a qualquer evoluçăo intelectual e moral, prendendo o artista ao conhecido e ao classificável e empobrecendo o caráter imaginativo da arte que provém dos sentimentos, é perfeitamente visível tanto nas fotomontagens quanto na lírica final de Jorge de Lima, assim como nas pinturas de Marc Chagall. Nesse sentido, o onirismo possibilitaria uma ampliaçăo do conhecimento, por năo estar preso estritamente ao racional. A imaginaçâo ganha reconhecimento e garante o aprofundamento da mente, antes aprisionada pela racionalidade.

De acordo com a teoria freudiana, o sonho é constituído, principalmente, por dois elementos: o conteúdo manifesto (o que conseguimos contar) e o conteúdo latente (o que necessitamos decifrar para interpretar o sonho - é uma espécie de chave para compreendermos os significados do sonho), esse aspecto demonstra o motivo pelo qual encontramos dificuldades na compreensăo dos sonhos. A sua caracterizaçăo básica encerra no sentido de que o sonho é sempre a realizaçăo de um desejo, mesmo que aparentemente se apresente de forma perturbadora ao sonhador.

De acordo com Freud, a atividade onírica de pensar năo ocorre em conceitos, como é característico do estado de vigília, mas pensa "predominantemente em imagens visuais - mas năo exclusivamente. Utilizam também imagens auditivas e, em menor grau, impressōes que pertencem aos outros sentidos." (FREUD, 2001, p. 67). Assim, "Os sonhos săo desconexos, aceitam as mais violentas contradiçôes sem a mínima objeçâo, admitem impossibilidades, desprezam conhecimentos que têm grande importância 
para nós na vida diurna e nos revelam como imbecis éticos e morais." (FREUD, 2001, p. 72). Desse modo, a "incoerência" das imagens oníricas se revela como característica essencial dos sonhos.

No mundo dos sonhos, há uma transformaçăo do espaço e do tempo como o concebemos no mundo da vigília; de acordo com Bachelard, perdem-se "suas forças de estrutura, suas coerências geométricas. O espaço onde vamos viver nossas horas noturnas nâo possui mais lonjura. É a síntese muito próxima das coisas e de nós mesmos." (BACHELARD, 1991, p. 160). Assim como ocorre com a concepçâo cronológica do tempo, que pode ser reorganizado.

Outra característica do sonho se refere a seu processo de deslocamento. Isto significa que uma imagem pode ter mais de um significado, pois, por analogia, pode-se transferir sentimentos e conceitos de uma a outra. No sonho, percebe-se também a facilidade para o trocadilho e a inversáo de termos, como se as palavras se comportassem como coisas. Essas características apontam a semelhança entre a formaçâo dos sonhos e a atividade artística.

Outro aspecto importante dos sonhos, apontado por Freud (através de uma citaçăo de Strümpell), refere-se ao fato de que estes

seguem seu curso, ao que parece, segundo as leis quer das representaçóes simples, quer dos estímulos orgânicos que acompanham tais representaçôes - isto é, sem serem de forma alguma afetados pela reflexăo, pelo bom senso, ou pelo gosto estético ou pelo julgamento moral (FREUD, 2001, pp. 75-76).

Nessa característica, constata-se a dessemelhança entre as atividades onírica e artística, pois a composiçăo do trabalho artístico se diferencia do sonho por ser concebido em grande parte conscientemente e nâo apenas pelo impulso da inspiraçáo.

A arte moderna da metade do século XIX e meados do XX se relacionará de maneira estreita com o onirismo. Para isso, ela năo tratará descritivamente os seus assuntos, conduzindo-nos ao âmbito do năo familiar, através de deformaçôes e estranhezas. No caso específico da poesia, a lírica moderna trocará formalmente o vocabulário usual pelo insólito; a sintaxe desmembra-se ou reduz-se a expressóes nominais intencionalmente primitivas; a metáfora e a comparação sâo aplicadas de uma maneira nova, forçando a uniăo do que parece ser inconciliável. Por estas características a arte moderna se apresenta de difícil compreensăo, tornando a surpresa e a estranheza seu conceito. Notoriamente é uma a arte que náo satisfaz um fruidor de hábitos fáceis. Tanto a lírica moderna quando as artes plásticas em geral nâo almejam a cópia do real, mas, sim, a sua transformaçăo. Para isto, o artista utilizará do sonho e da fantasia, caminhos mais favoráveis para elevar sua capacidade criativa. Assim, a aspiraçáo anterior à cópia é contraposta à fantasia e ao sonho, proporcionando o enriquecimento e aumentando imensamente a possibilidade criativa do artista moderno (Cf. FRIEDRICH, 1991, pp. 18-19).

\section{Marc Chagall}

Marc Chagall (1887-1953), de origem judaica, iniciou-se na pintura na pequena cidade russa de Vitebsk ${ }_{\llcorner}$dando continuidade a seus estudos em Sáo Petersburgo e em 
Paris, onde viveu de 1910 a 1914. Ao chegar à França, Chagall se impressiona com as luzes da cidade de Paris - muito diferentes do ambiente escuro da Rússia -, descobre um universo novo, que influenciaria profundamente sua arte.

Em Paris, o pintor se comove com o Cubismo. Amigo de poetas e escritores, foi Guillaume Apollinaire, Max Jacob e Blaise Cendrars que o estimularam a ficar no país, em plena efervescência artística, com seus variados movimentos de vanguarda. É visível na obra do pintor a influência do movimento Surrealista. Tanto Chagall quanto o Surrealismo procuram exaltar o sonho e o inconsciente, excedendo as leis do mundo físico. O tempo presente e o tempo passado unem-se para formar o "instante", rompendose as fronteiras entre o ontem e o hoje, que coexistem no inconsciente humano. Argan diz que "A pintura de Chagall é fábula, mas a fábula é problemática. Nâo poderia deixar de sê-lo numa sociedade que após uma revoluçăo ideológica, considerava-se adulta." (ARGAN, 1992, p.471). Esse caráter fabular de sua pintura é visto pelo crítico como "uma expressăo viva da criatividade do povo". (ARGAN, 1992, p. 471), que pode ser observado nas representaçōes das pequenas aldeias russas em suas pinturas.

Apollinaire classificou-o de "'sobrenatural' ('sur-naturel'), que depois substituiria por 'surréaliste'; 'irrealismo' seria proposto mais tarde (M. GEORGES-MICHEL, 1944) - melhor convindo à inocência duma arte de apariçôes e sonhos, feita de imagens sem peso, de caráter 'hipnagógico' (A. Breton)." (FRANÇA, 1987, p. 332). Chagall foi um criador de "novas situaçōes poéticas" (FRANÇA, 1987, p. 333) por meio do imaginário. Apesar da viva semelhança com o Surrealismo, năo podemos considerá-lo um artista surrealista de primeira ordem, pois o pintor, muito antes do encontro com essa tendência estética parisiense, já trazia consigo uma visáo poética do inconsciente, do ilógico e da percepçấo intuitiva, contrapondo-se ao pensamento racional. Nesse sentido, a relaçấo do pintor com o mundo fabular e/ou fantástico vem de longa data. O Surrealismo, portanto, năo foi a expressăo artística que o estimulou a criar seu mundo onírico visível na composiçăo simbólica de suas obras, seja pela libertaçăo da composiçáo das cores, no rompimento com o desenho formal, como também pela quebra da perspectiva realista em suas representaçōes do mundo. Com a eliminaçăo do "racionalismo" em sua poética, o pintor russo pretendia revelar a "realidade psíquica profunda" (ARGAN, 1992, p. 472) do indivíduo. Para Argan, Chagall "transpōe o limiar do domínio sem fim do inconsciente individual e coletivo." (ARGAN, 1992, p. 472). Nesse sentido, o crítico aponta que Chagall se aproxima de uma experiência sensorial contígua ao plano da psique.

Antes, năo era possível tornar visível a realidade psíquica profunda, porque a tela sensorial estava preventivamente organizada pela razăo: via-se de acordo com a ordem lógica pré-constituída. Agora náo mais; o Impressionismo, com tudo o que veio a seguir, desmontou esta superestrutura racional. $O$ ver é um fato físico, mas a realidade física năo está absolutamente separada da realidade psíquica (ARGAN, 1992, p. 473).

Chagall criou um estilo particular em que a imaginaçâo dá autonomia aos objetos e personagens da realidade, libertos da lei da gravidade e do tempo. Em suas pinturas, sempre buscou retratar o povo: camponeses, aldeóes, amantes, animais e o mundo do circo, lembranças de sua terra natal, a cidade de Vitebsk, na Rússia. Também se pode notar na obra do artista as figuraçóes fabulares, das narrativas bíblicas, dos ícones ortodoxos russos e do cotidiano judeu.

Chagall exercia uma imaginaçăo desafiadora. Montava elementos díspares de maneira semelhante aos surrealistas. No entanto, ultrapassava um estilo artístico 
único. Pois também é visível, em sua obra, características do cubismo, do simbolismo, do fauvismo e do orfismo. Criou uma obra que emana uma "fabulaçấo visual". De acordo com Argan, isto pode ser notado nos procedimentos do artista:

Decompondo figuras, casas, céus, segundo planos geométricos, cria uma espécie de perspectiva arbitrária, um espaço impossível, onde se torna normal o absurdo da vaca no telhado, da mulher que anda pelo ar; a geometria năo é lógica, é cabala. Subvertida a sucessăo ordenada, racional, dos planos, náo surpreende que tudo caminhe ao contrário, como nos sonhos (ARGAN, 1992, p. 473).

O pintor russo é considerado o responsável por fundir a poesia e as artes plásticas. Após o ano de 1922, começa a fazer ilustraçóes para as fábulas, de La Fontaine, e para Almas Mortas, de Gogol e, nos anos 1930, ilustra a Bíblia. A Bíblia foi fonte de inspiraçâo constante para o pintor. Na primeira metade dos anos 1930, ele trabalha em uma série de guaches sobre temas bíblicos com grande expressividade. E, em 1966, dedica-se a uma série denominada "Mensagens bíblica", formada por dozes obras: "A criaçăo do homem", "O paraíso", "Adăo e Eva expulsos do paraíso", "A arca de Noé", "Noé e o arco-íris", "Abraâo e os três anjos", "O sacrifício de Isac", "O sonho de Jacó", "A luta de Jacó e o anjo", "Moisés e o espinheiro ardente", "A rocha que emana água" e "Moisés recebendo as tábuas da lei".

\section{"0 grande desastre aéreo de ontem"}

"O grande desastre aéreo de ontem" é um poema em prosa que Jorge de Lima dedica ao pintor Cândido Portinari. Em termos sintéticos, o poema trata de um acontecimento conhecido por uma notícia de jornal, que o poeta, por meio de uma visâo onírica, elenca objetos, seres e situaçôes participantes de um desastre de aviâo. Portanto, o poema é uma espécie de transfiguraçăo poética de um acontecimento real, que transforma um fato prosaico em poesia, por meio do trabalho com a linguagem, no uso do onirismo, de metáforas singulares, imagens visuais, ritmo intenso, etc. Tal trabalho faz com que um acontecimento real atinja o estatuto literário, válido por si mesmo.

De acordo com Aleílton Fonseca, o poema

se desenvolve a partir de uma imagem básica, "sangue/cor", que é reiterada duas vezes, retomando o fôlego lírico: "Vejo sangue no ar" e "chove sangue". Esta imagem dá a tonalidade pictórica do poema, fixa o quadro, estabelecendo a ideia de um instantâneo, como uma pintura moderna, com o motivo no primeiro plano de visâo que "choca", trazendo de permeio os detalhes. ${ }^{6}$

José Niraldo de Farias acrescenta que "a repetiçâo insistente do verbo 'ver' denuncia a preocupaçáo em materializar pictoricamente a cena descrita." (FARIAS, 2003, p. 72). Para transfigurar esse acontecimento, o poeta elabora uma "lógica" nova, do mundo onírico, que nos remete diretamente à poética chagalliana. É visível a ressonância desse mundo imagético do pintor russo no poema limiano, que pode ser notada nas representaçōes figurativas elencadas anteriormente: "A dança”, “Obsessāo”, "O sonho

6 Disponível em: http://www.jornaldepoesia.jor.br/ali01.html. Acesso em 30 de nov. 2016. 
de Jacob", "Cantar dos cantares" e "Amantes no céu vermelho", etc. Nessas obras (no poema e nas representaçóes picturais), podemos notar um ambiente onírico-religioso, em que aparecem seres flutuantes, amantes em estado de êxtase em meio a buquês de flores coloridas, onde uma noiva corta o céu rápido como um cometa. A cor vermelha se sobressai em meio a mistura de elementos, muitas vezes díspares, num ambiente sensual.

A elaboraçấo de "O desastre aéreo de ontem" nos remete a collage surrealista, técnica proveniente dos papiers collés cubistas, que consistia em aproximar duas realidades diferentes num plano que năo lhes era próprio, provocando uma imagem inusitada, diferenciada do corriqueiro e do lógico; próxima, portanto, como dissemos, do mundo do sonho. Essa técnica ajuda o poeta a fortalecer a criaçấo imagética de seu poema, a partir da uniâo de elementos muitas vezes simples que, por causa de sua combinaçáo, se tornam inusitados, fornecendo uma atmosfera mágica, muitas vezes enigmática e insólita - o que nos dá a sensaçâo de estar em contato com uma imagem nova. Este procedimento nos remete diretamente às colagens praticadas por Jorge de Lima, iniciadas no mesmo período da elaboraçáo de A Túnica Inconsútil. Dessa maneira, vemos, no poema, o encontro inesperado, no ar, do "piloto, que levava uma flor para a noiva, abraçado com a hélice", a "louca abraçada ao ramalhete de rosas que ela pensou ser o pára-quedas", a "prima-dona com a longa cauda de lantejoulas riscando o céu como um cometa", o "paralítico" que "vem com extrema rapidez, vem como uma estrela cadente, vem com as pernas do vento" - imagens que remetem a passagem do cometa Halley em 1910, fenômeno que encantou diversos artistas da época ${ }^{7}$ imagens que os "poetas míopes", que ao ver a chuva de sangue nas nuvens, "pensam que é o arrebol."

É também possível perceber em algumas imagens do poema, revelado por versos como o "sino que ia para uma capela do oeste" vem "dobrando finados pelos pobres mortos", a referência a sensibilidade lírico-religiosa do poeta, que anuncia a passagem da vida para morte. O rito de passagem para o encontro com incognoscível se realiza plenamente no final do poema, que de uma maneira corriqueira, como a passagem do dia para a noite, se passa da vida para a morte: "Chove sangue sobre as nuvens de Deus. E há poetas míopes que pensam que é o arrebol."

De acordo com Fábio Andrade, em "O grande desastre aéreo de ontem", "um acidente mecânico é alçado ao nível de uma desgraça cósmica, apocalíptica" (ANDRADE, 1997, p. 78). Esta percepçáo é visível, segundo o crítico, pelo acúmulo no poema de "imagens insólitas", os "reconhecíveis ecos chagallianos" e "a ênfase no sujeito" (revelada na recorrência do verbo "ver"), estabelecendo "pontes simbólicas que evidenciam semelhanças entre dois objetos ou seres năo conaturais, criando sistemas de relaçōes analógicas năo correntes ou recriando as legadas pela tradiçăo." (ANDRADE, 1997, pp. 73-74).

7 De acordo com Ana Maira Paulino, este poema seria uma espécie de exemplo do impacto da passagem do cometa entre nós. Jorge de Lima assim comenta a sensaçăo que teve com a passagem do cometa: "Nuns dias de febre [...] percebi um ente cujos olhos eram dois imensos algodóes ardentes, o nariz como um rochedo de estanho derretido [...] as máos eram dois cometas, a fala de ventania quente, a boca de lua, roupagens de arco-íris, os cabelos misturados de nuvens [...] por uns vinte dias, as noites de febre foram povoadas de verdadeira chuva de estrelas cadentes. Lau me convenceu que eram pragas de morcegos [...] que de noite ficavam luminosos, riscando o céu. [...] minha mâe [...] me convenceu que deveriam ser sinais do céu, prenunciando o cometa de Halley, acontecido anos depois" (LIMA apud PAULINO, 1995, p. 29). 
Um bom exemplo que reforça a ideia de que o poema é realizado por meio do procedimento da montagem ou colagem poética, à maneira surrealista, pode ser percebido na imagem básica do poema: a junçấo de um elemento do mundo prático cotidiano, o aviăo, ao topo da morte, revelado pelo fim do dia, associado ao fim da vida. Dessa maneira, dois elementos opostos se juntam, formando uma imagem insólita, própria das realizadas pela montagem surrealista. 0 mesmo também podemos notar nas bailarinas graciosas e na bela nadadora que rompem seus corpos em meio a chuva de sangue: "măos e pernas de dançarinas arremessadas na explosáo", a "nadadora belíssima, no seu último salto de banhista, mais rápida porque vem sem vida", as "três meninas caindo rápidas, enfunadas, como se dançassem ainda".

Em um processo análogo à colagem surrealista, no Brasil, Jorge de Lima praticou o que aqui se denominou de fotomontagem. O seu livro Pintura em Pânico (1943), prefaciado por Murilo Mendes, produziu grande interesse por parte de alguns críticos. Para compreendermos bem o processo pelo qual Jorge de Lima elabora seu poema, vejamos como Mário de Andrade nos explica o processo de criaçăo da fotomontagem. De forma entusiasta, o poeta e crítico paulista associa a fotomontagem ao jogo lúdico da brincadeira infantil:

A fotomontagem parece brincadeira, a princípio. Consiste apenas na gente se munir de um bom número de revistas e livros com fotografias, recortar figuras, e reorganizá-las numa composiçáo nova que a gente fotografa ou manda fotografar. A princípio as criaçôes nascem bisonhas, mecânicas e mal inventadas. Mas aos poucos o espírito começa a trabalhar com maior facilidade, a imaginaçăo criadora apanha com rapidez, na coleçấo das fotografias recortadas, os documentos capazes de se coordenar num todo fantástico e sugestivo, os problemas técnicos da luminosidade săo facilmente resolvidos, e, com imensa felicidade, percebemos que, em vez de uma brincadeira de passatempo, estamos diante de uma verdadeira arte, de um meio novo de expressăo! (ANDRADE, 1987, p. 09).

Murilo Mendes caracterizou o processo da feitura da fotomontagem como desforra contra a restriçấo e a ordem, também a associando à infância.

A fotomontagem implica uma desforra, uma vingança contra a restriçăo de uma ordem do conhecimento. Antecipa o ciclo de metamorfoses em que o homem, por uma operaçáo de síntese da sua inteligência, talvez possa destruir ao mesmo tempo.

Liberdade poética: este livro respira, a infância dá a mâo à idade madura, a calma e a catástrofe descobre parentesco próximo ao folhearem um álbum de família (MENDES, 1987, p.12).

Otto Maria Carpeaux, em introduçâo à Obra Poética de Jorge de Lima, organizada por ele, dizia que quando "as palavras já năo pareciam capazes de exprimir tudo aquilo que o poeta [Jorge de Lima] pretendeu dizer, recorreu ao recurso da fotomontagem" (CARPEAUX, 1949, p.VII). Acrescenta-se a esta perspectiva uma outra, a de Murilo

8 É importante lembrar que as fotomontagens de A pintura em Pânico, publicadas em 1943, foram, em sua grande parte, compostas três a quatros anos antes. Isso quer dizer que foram realizadas em plena Segunda Guerra Mundial. Diante disso, mais que uma simples técnica artística, a fotomontagem pode ser considerada uma expressấo da vida moderna fragmentada, múltipla e caótica de uma sociedade esfacelada pela guerra. Soma-se a isso, o início das crises depressivas pelas quais o poeta passara no final dos anos trinta. Nâo é difícil perceber essas intensas perturbaçōes que passam tanto o poeta quanto o mundo nas várias fotomontagens do livro, assim como em algumas de suas legendas. 
Mendes, que considerava o procedimento da fotomontagem como uma forma de resistência ao mundo presente:

"As catacumbas marinhas contra o despotismo", "Morta a reaçăo, a poesia respira", além de outras, săo imagens de um mundo que resiste à tirania, que se aparelha contra o massacre do homem, o aniquilamento da cultura, a arte dirigida e programada (MENDES, 1987, p. 12).

É a partir dessa perspectiva, uma espécie de reconfiguraçăo do mundo por meio de elementos opostos, que a poesia moderna trabalhará a imagem em sua criaçăo poética. Um exemplo claro disso pode ser notado nas palavras de um dos seus grandes representantes, o poeta-crítico Octavio Paz, quando caracteriza a imagem através da identidade de elementos contrários.

Épica, dramática ou lírica, condensada em uma frase ou desenvolvida em mil páginas, toda a imagem aproxima ou conjuga realidades opostas, indiferentes ou distanciadas entre si. Isto é, submete à unidade a pluralidade do real. Conceitos e leis científicas náo pretendem outra coisa. [...] A imagem resulta escandalosa porque desafia o princípio de contradiçấo: o pesado é o ligeiro. Ao enunciar a identidade dos contrários, atenta contra os fundamentos do nosso pensar. Portanto, a realidade poética da imagem náo pode aspirar à verdade. $O$ poema náo diz o que é e sim o que poderia ser. Seu reino năo é o do ser, mas o do "impossível verossímil" de Aristóteles (PAZ, 1972, p. 38).

Na conjugaçăo de elementos opostos também há o momento da convergência desses termos. Nessa ocasiăo, como nos diz o crítico, "[...] pedras e plumas, o leve e o pesado, nascer-se e morrer-se, ser-se, săo uma e mesma coisa." (PAZ, 1972, p. 42). Desse modo, a imagem poética funde elementos muitas vezes díspares numa espécie de renomeaçăo e recriaçăo do mundo, de modo que o poeta, como no tempo primitivo, nomeia novamente as coisas. Para Octavio Paz, "a imagem pode dizer o que, por natureza, a linguagem parece incapaz de dizer" (PAZ, 1972, p. 44).

Outro ponto importante para o crítico diz respeito ao fato de que náo precisamos recorrer a outras palavras para explicar a imagem, pois o seu sentido está nela mesma.

A imagem reconcilia contrários, mas esta reconciliaçăo năo pode ser explicada pelas palavras - exceto pelas da imagem, que já deixaram de sê-lo. Assim, a imagem é um recurso desesperado contra o silêncio que nos invade cada vez que tentamos exprimir a terrível experiência do que nos rodeia e de nós mesmos. 0 poema é linguagem em tensăo: em extremo de ser em ser até o extremo. Extremos da palavra e palavras extremas, voltadas sobre a as suas próprias entranhas, mostrando o reverso da fala: o silêncio e a năo significaçăo. Mas aquém da imagem, jaz o mundo do idioma, das explicaçôes e da história. Mais além, abrem-se as portas do real: significaçăo e năosignificaçăo tornam-se termos equivalentes. Tal é o sentido último da imagem: ela mesma (PAZ, 1972, p. 49).

Portanto, uma poesia imagética como a praticada por Jorge de Lima aumenta muito a possibilidade criativa da utilizaçâo da metáfora. No dizer de Hugo Friedrich, a metáfora é o "meio estilístico mais adequado à fantasia ilimitada da poesia moderna" (FRIEDRICH, 1991, p.206), e ela nâo nasce da necessidade de reconduzir conceitos desconhecidos a conceitos conhecidos: "Realiza o grande salto da diversidade de seus elementos a uma unidade alcançável só no experimento da linguagem [...]". (FRIEDRICH, 1991, p. 207). Nas palavras de Reverdy, "a imagem é uma criaçăo pura do espírito" e é 
"próprio da imagem forte ter nascido da aproximaçăo espontânea de duas realidades muito distantes de que só o espírito percebeu as relaçōes" (REVERDY apud RAYMOND, 1997, p. 249). Nessa perspectiva, querer traduzi-la é o mesmo que matá-las.

É interessante notar que essas mesmas consideraçōes feitas à criaçāo das imagens no poema, de alguma forma, podem ser transpostas ao universo imagético da pintura moderna, em suas expressóes mais imaginativas. No caso específico de Marc Chagall, como nos aponta Argan, há na obra do pintor russo uma raiz simbólica em sua representaçâo imaginativa da realidade, na qual

Há, na raiz, uma simbologia das cores; qual é o símbolo, năo importa saber, ou melhor, năo se deve saber, pois do contrário o encanto seria rompido. Ou melhor, sabe-se no inconsciente: o símbolo é a linguagem do inconsciente, como a lógica o é da consciência; e o símbolo deve permanecer inconsciente e hermético, justamente porque é ilógico em si, náo se podendo admitir logicamente que o mesmo signo signifique duas coisas diferentes (ARGAN, 1992, p. 473).

Situaçáo visível na obra do pintor quando, por exemplo, vemos uma mulher flutuar normalmente pelo céu de uma pequena vila russa e nâo acreditamos nos nossos próprios olhos. Assim, de acordo com o crítico:

É precisamente esta a situaçâo que Chagall quer determinar, no tocante ao quadro: o que se pede à fábula é que seja inacreditável. O processo de Chagall é, em certo sentido, um processo de transliteraçăo, semelhante ao de Breughel, quando dá figuraçáo aos provérbios flamengos: transpóe para imagens visuais as palavras de um texto (ARGAN, 1992, p. 473).

Assim, a grande descoberta da arte moderna, seja ela a poesia ou a pintura, revela que a fonte da linguagem "é a imaginaçâo, nâo a lógica, mas que a imaginaçâo, tal como a lógica, possui uma estrutura própria e cumpre uma funçấo 'construtiva."' (ARGAN, 1992, p. 473). 


\section{Referências Bibliográficas}

ANDRADE, Fábio de Sousa. 0 engenheiro noturno: a lírica final de Jorge de Lima. Sáo Paulo: Editora da Universidade de Săo Paulo, 1997.

ANDRADE, Mário de. Nota preliminar a A Túnica Inconsútil. In: LIMA, Jorge de Lima. Obra Completa (Org. Afrânio Coutinho). Rio de Janeiro: Aguilar, 1958, vol. I.

.Fantasias de um Poeta.In:Paulino, Ana Maria(Org.)OPoeta Insólito-Fotomontagens de Jorge de Lima. São Paulo: IEB/USP, 1987.

ARGAN, Giulio Carlo. "Marc Chagall: À la russie, au ânes et aux autores”. In: Arte moderna: do Iluminismo aos movimentos contemporâneos. Sáo Paulo, Companhia das Letras, 1992.

BACHELARD, Gaston. 0 direito de sonhar. Rio de Janeiro: Bertrand Brasil S. A., 1991.

BASTIDE, Roger. Jorge de Lima. In: Poetas do Brasil. Sáo Paulo: EDUSP; Duas Cidades, 1997.

Bíblia Sagrada. Petrópolis, Editora Vozes, 2004.

BOSI, A. Jorge de Lima. In: História concisa da literatura brasileira. Săo Paulo. Cultrix, 1999.

CANDIDO, Antonio. A revoluçăo de 1930 e a cultura. In: A Educaçăo pela noite e outros ensaios. Sâo Paulo: Ática, 1987.

CARPEAUX, Otto Maria. Organizaçăo e Introduçăo a Obra Poética - Jorge de Lima. Rio de Janeiro: Editora Getúlio Costa, 1949.

CAVALCANTI, Luciano Marcos Dias. Metamorfoses de Orfeu: a "utopia" poética na lírica final de Jorge de Lima. Sáo Paulo: Todas as Musas; Belo Horizonte: Fapemig, 2015.

FARIAS, José Niraldo de. 0 Surrealismo na poesia de Jorge de Lima. Porto Alegre: Editora PUCRGS, 2003.

FRANÇA, José Augusto. História da arte ocidental (1780-1980). Lisboa, Livros Horizonte, 1987.

FREUD, Sigmund. A interpretaçăo dos sonhos. Rio de Janeiro: Imago, 2001.

FRIEDRICH, Hugo. Estrutura da lírica moderna: problemas atuais e suas fontes. Săo Paulo: Duas Cidades, 1991.

FONSECA, Aleilton. "Um poema de Jorge de Lima". In: Jornal de Poesia. http://www.jornaldepoesia.jor.br/ali01.html. Acesso em 16-12-2016

GONÇALVES, Aguinaldo José. “Relaçōes homológicas entre literatura e artes plásticas: algumas consideraçóes". In: Literatura e Sociedade, n. ํ 2. Săo Paulo: FFLCH, 1997.

LIMA Jorge de. Obra Completa (org. Afrânio Coutinho). Rio de Janeiro: Aguilar, 1958.

Poesia Completa: volume único (org. Alexei Bueno; textos críticos, Marco Lucchesi... [et al.].). Rio de Janeiro: Nova Aguilar, 1997. 
MARC, Chagall. Museu e coleçăo Marc Chagall. <http://en.musees-nationaux-alpesmaritimes.fr/chagall/node/10>. Acesso em 30-10-2017

MARC, Chagall. <https://www.wikiart.org/pt/marc-chagall>. Acesso em 30-10-2017

MENDES, Murilo. Nota liminar. In: Paulino, Ana Maria (org.) 0 Poeta Insólito Fotomontagens de Jorge de Lima. Săo Paulo: IEB/USP, 1987.

PAULINO, A. M. Jorge de Lima. Sāo Paulo: EDUSP, 1995 (Série Artistas Brasileiros).

PAZ, Octavio. Signos em rotaçâo. Sāo Paulo: Perspectiva, 1972.

RAYMOND, Marcel. De Baudelaire ao surrealismo. Săo Paulo: EDUSP, 1997. 